\title{
Ecological Wisdom in Slash Burning Farming of Remote Indigenous Community in North Mamuju Regency
}

\section{Saleh S. Ali*, Rahmadanih}

Department of Agricultural Socio Economics, Faculty of Agriculture, Hasanuddin University, Indonesia.

*Corresponding author e-mail: saleh.assofie@gmail.com

How to Cite: Ali, M.S.S., \& Rahmadanih. (2017). Ecological Wisdom in Slash Burning Farming of Remote Indigenous Community in North Mamuju Regency, Int. J. Agr. Syst. 5(2): 207-215.

\begin{abstract}
The slash and burning system is a farming system that is the most widely practiced in many places in the world. The System is generally sedentary from one place to others. Slash and burning community has developed ways to cultivate the fields so that it becomes an integral part of their cultural system. This paper aims to explain the sociocultural of remote indigenous communities in practicing slash and burning farming in North Mamuju Regency, West Sulawesi, Indonesia. This study was designed with a qualitative approach using ethnographic tradition. Data collected through interviews for selected snowballing and FGD (Focus Group Discussion). The informants include residents of the indigenous communities, indigenous elders, village heads and local government officials. The results of this study indicate that slash burning farming is done by indigenous communities in North Mamuju Regency for generations. Totua Panggare' or Bangunasa. Rice for people in the region understood as a manifestation of the ancestral spirits that must be respected or treated well like to humans treat. All the activities of farming are filled with rituals as a manifestation of their culture.
\end{abstract}

Copyright (C) 2017 IJAS. All rights reserved.

Keywords:

Socio-culture; slash and burning farming; indigenous people

\section{Introduction}

Slash and burning system is a farming that most of the world practiced in many parts of the world. This system is generally sedentary from one place to others and is an integral part of a community cultural system. In Asia, all agricultural systems are initiated into this system (Mulyoutami et al., 2010). Slash and burning system is done by a group of people to meet the needs of the people by slashing and burning forest and it generally has done on a shifting base (Mulyoutami et al., 2010). The slashing and burning farming system is still largely practiced, especially in isolated communities by using simple tools and technology. The isolated community is a society that lives apart from the general public and has a different lifestyle and cultural value from the general public. There are 3 categories of isolated communities (Dharmakusuma, 2008), namely (1) Fully sedentary isolated communities. These communities live sedentarily from one place to another. Their lives are very simple and meet their food from hunting, fishing, 
or gathering from a forest. They are led by a group leader. This type of isolated community is rare contact or associate with outsiders. (2) Half sedentary isolated community. This type of community is a little more advanced than fully sedentary isolated community. They open the forest and planting seasonal crops and after harvest they move to another area and again open up new land, and until a certain period they return to cultivate the abandoned land. (3) Temporary settlement sedentary, which are slightly more advanced than the one of them, they are still practicing slash-burning, but have been in contact with people outside the community through sell-buy activities.

According to Iskandar (1992) and Soemarwoto (2001), slash burning farming is the best adaptation of society with low technological and soil fertility levels. If they did not engage in shifting cultivation, there would be enormous environmental damage. Michael R. Dove (1985) who studied for many years of the pattern of slash and burn cultivation concluded that the best and most rational adaptation of indigenous peoples to their natural and social environments is shifting cultivation, it does not damage the sustainability of renewable natural resources in the form of forest and soil fertility. Indigenous peoples have successfully developed ecological wisdom that has been firmly adhered to as a guide to sustainable management of forest resources. In West Sulawesi is an isolated tribe known as Tori Bunggu. Since 1992 this tribe is named as Remote Indigenous Communities (KAT) or Remote Customary Community after the Indonesian Indigenous Peoples Congres. The community lives scattered in groups and settles in four sub-districts namely Pasangkayu, Pedongga, Bambalamotu and Bambairotu Sub-District (Rahmadanih, 2010). The community of Tori Bunggu in fulfilling their foods and other needs is by opening forest with slash and burning practices sedentarily. The way they cultivate based on inheritance to the generation of their generation of ancestors. They develop knowledge or wisdom in keeping their ecology in farming. This knowledge can be called as indegenous knowledge, local knowledge or traditional knowledge (Ali, 2000; Husnah et al., 2014). Such knowledge is created by a group people who lives in close contact with nature over a long period of time; passed down from their ancestor to current generation; constant improvements and integrated to the existing; the creation and improvement is a group effort; stored in people' memories and activities (Kamaluddin et al., 2016). Based on the above, this article aims to explain how the ecological wisdom of remote indigenous communities in North Mamuju in doing farming.

\section{Method}

The method used in this research is qualitative method by using ethnographic tradition supported by focus group discussion method and participant observation. The research was conducted in Kabupaten Mamuju Utara (North Mamuju Regency), West Sulawesi Province, Indonesia. The unit of analysis is a remote indigenous community (Tori Bunggu community that has settled permanently). In-depth interviews were conducted by using an open questionnaire to obtain information about local wisdom of shifting cultivation practices. There were 9 informants from the member of the community were selected by snowball technique. In addition to that, we interviewed also some informants outside of the community that were considered have knowledge about the origin and civilization of Tori Bunggu community and the policies that have been implemented in that community. In addition to in-depth interviews, Focus Group Discussions (FGD) was also held, with the members of the Tori Bunggu community (including Totua panggare, Totua nu boya, Totua mampakoni), and shifting 
cultivators. In accordance with the conditions of the field, the FGD was only held once for each residential group.

\section{Results and Discussion}

\subsection{Knowledge about slash-burning farming}

The indigenous community of Tori Bunggu has practiced slash-burning farming from generation to generation and is an integral part of their culture. Understanding and perceptions of informants on shifting cultivation systems in North Mamuju District is shown in Table 1.

Tabel 1. Perceptions of informants about shifting cultivation systems in North Mamuju District.

\begin{tabular}{ccccccc}
\hline \multirow{2}{*}{ Informant } & \multicolumn{7}{c}{ Perceptions of informants } \\
\cline { 2 - 7 } & $\begin{array}{c}\text { Tradition } \\
\text { (hereditary) }\end{array}$ & $\begin{array}{c}\text { Work with } \\
\text { a group }\end{array}$ & $\begin{array}{c}\text { Planting } \\
\text { local } \\
\text { varieties }\end{array}$ & $\begin{array}{c}\text { Land is follow } \\
\text { without } \\
\text { fertilizer }\end{array}$ & $\begin{array}{c}\text { The fallow } \\
\text { period is } \\
\text { getting shorter }\end{array}$ & $\begin{array}{c}\text { Production } \\
\text { decrease }\end{array}$ \\
\hline 1 & +- & +- & +- & +- & +- & +- \\
2 & ++ & ++ & ++ & ++ & ++ & ++ \\
3 & ++ & ++ & ++ & ++ & ++ & ++ \\
4 & ++ & ++ & ++ & ++ & ++ & ++ \\
5 & ++ & ++ & ++ & ++ & ++ & ++ \\
6 & ++ & ++ & ++ & ++ & ++ & ++ \\
7 & ++ & ++ & ++ & ++ & +- & ++ \\
8 & ++ & ++ & ++ & ++ & +- \\
\hline
\end{tabular}

Source: Result of Indepth-Interview, 2010

Note :

$++=$ Know \& active practicing slash-burning farming.

+- $=$ Know but no active practicing slash-burning farming.in the last 3 years.

The point is that the shifting cultivation system in North Mamuju Regency is a system that was carried out for generations. The system was practiced in groups of the leadership of one of the indigenous leaders called Totua Panggare/Bangunasa (a customary figure who specializes in swiddens). Residents of KAT, which is often also called To ri Bunggu, implement shifting cultivation system by planting rice local varieties. The shifting activity is done in groups of a field called langa. Each person or family has one plot of rice fields in the langa. The fields in a langa they call bonta. The boundary of each bonta is called panjoi which is marked with a plant called rodo. Given the limits of rodo crop, the boundaries of each bond are still known, even though the field has turned into forests again. In doing shifting farming system, the community was guided by adat rules (customary rules and beliefs). The customary rules or norms are the procedures in practicing the shifting cultivation system from land preparation to harvesting stage. They believe that shifting cultivation systems as the cheapest agricultural practice because they did not need to use artificial fertilizers, just by resting the land. The longer the land is rested, the more land will be fertile.

\subsection{Meaning of Rice for KAT Residents}

Although the production of paddy tends to decrease, this commodity is still grown every year by KAT people considering the commodity has its own meaning for KAT people. The meaning of paddy field production of KAT citizens is relatively the same, depending on their perception of the commodity. The KAT community understood that the production of rice is the embodiment of the ancestral spirits. So it must be 
valued or treated as well as treating humans. Post-harvest processing should be done on indigenous land (land where rice grows) which they understand as indo (mother). Rice production may be brought to residential areas after being processed into rice. Another meaning is that the harvest of paddy should not be sold, either in the form of grain or in the form of rice but may be given to the relatives or others as far as the person concerned and respects the rice harvest by To ri Bunggu (produced on customary land).

\subsection{Slash-Burning Practices of KAT To Ribunggu}

The activity of preparing the land to be cultivated is usually carried out in July. These activities include searching for land, plotting the land, asking permission to Viata, setting up individual land plots, opening the land (clearing and logging of large trees), drying and burning.

(a) Searching land for cultivation (haota mampali tana bone'/ hau' mampali ova).

Before starts farming, the KAT community (led by Totua Panggare') searches suitable land to be used for farming by clearing or cutting down trees. For this purpose, a ritual activity is done to determine whether the land or field can be used or not.

(b) Determining land for cultivation (pilihi langa).

Any KAT citizen that will open a peace of land to be cultivated, has to inform first the customary leader (Totua Panggare'). If one fail to inform the Totua Panggare about his will, he will be fine a set of dulang plate.

Activities undertaken in connection with the process of settling the land claimed by KAT residents living in Bamba Apu are as follows:

- In the morning, Totua Panggare 'sticks two large wooden statues decorated with rattan leaves that resemble a man who symbolizes a husband and wife. This is intended that through the couple, KAT citizens (through the Totua Panggare') pleading guidance to the gods or spirits about whether or not a proper forest area to be used for farming.

- Furthermore, the Totua Panggare' takes soil through both palms of his hands and kissed it while praying (ask for clues). In the evening, the Totua Panggare' usually "dreams". If the Totua Panggare' dreamed of fruits (usually lansat or durian), then the land that has been pegged can be opened for farming because it is considered feasible for food crops, especially for rice and corn crops. However, if the Totua Panggare' is dreamed of a fruit or durian, then the fruit suddenly disappears when approached by the Totoa Panggare', then the land that has been pegged should not be opened because it is believed will not give results. Thus, the wooden pegs that have been installed must be moved to elsewhere.

- If three days after the installation of wooden stakes but the Totoa Panggare' does not dream, then the Totoa Panggare' did another way as is commonly done by other KAT residents is providing 2 chickens (one male and one female) to one mountain/forest area. One of the chickens is loose in the forest and the other is cut to be examined for his heart. There is a belief among the KAT citizens that the harder the chicken heart, the better the land to be used for farming. In addition, there is also the belief of the KAT citizens that by releasing chickens freely in nature they can be protected from any kind of disturbance by anyone or anything. When the chicken will be releasing, it usually begins with a saying: taalami ovai, manu'mi nala iyya (we take the land and you grab the chicken). The meaning of chicken release is: if there is danger that will 
disturb the residents, then the danger goes with the chicken. So it does not interfere with the citizens.

- Another way is to insert machetes or bamboo strands into the soil. When the machete is lifted and there is sticky ground, it is believed by KAT residents that the soil is fertile enough to be used for farming. Similarly, when the bamboo segment is revoked and the land left in the bamboo segment does not fall out.

(c) Asking Permission to Viata (merapi belo' ritumpu tana).

After having certainty about the fertility of the land, then they held a ceremony to ask permission to viata by doing mompepoyu (farewell to read the prayers). The main requirement for this activity are to slaughter at least one pig or at least six chickens (three males and three females) performed by a customary figure. In the last ten years, the KAT who live in Bambamone hamlet it is only use chickens with the consideration that this practice is always carried out by his ancestors and agreed by the citizens. Meanwhile, the KAT residents that live in Tosonde hamlet use pigs as means as commonly practiced by their ancestors of generation of generation.

(d) Determining the land (pilihi bonta).

Land (bonta) that will be used for farming, it was set after asking permission to viata. In general, in one mountain (langa area) consists of 9 - 13 plots/bonta (according to mountain conditions and number of prospective land managers). In accordance with the customary norms that the land that has been opened, the right to use the land belongs to a group of the KAT citizens. The collective rights of the people will increase if more forest areas are opened because they already have a rule that "the land that has been opened by one of the citizens in a forest area, can no longer be opened by other people even if it is in one group, except with the relevant permits from the residents who cultivated before)".

Total land area of each household range of 0.50 - 1.50 hectare (Depending on the amount of labor involved in each household because there are no customary rules that limit the size of the land for each family).

(e) Slashing (Mantalu).

After the ritual (ask permission on viata), then the next step is clearing the land by slashing shrubs and trees on the land already plotted. This activity is carried out using a machete and / or sickle. From indepth-interview it is known that "slashing" activities were carried out in mutual help by the KAT citizens. However, when the KAT residents have settled on low land, where they were growing cocoa or other crops on permanent land (with legal right), resulting in frequent mutual-help activities such as mengimas which was sometimes performed independently. Within the last ten years, many KATs groups whose members do mengimas activities individually compared to mutual-help.

\section{(f) Cutting Bush and Trees (Motovo).}

The work of cutting down the bushes and the trees must consider the time, namely before it rains so that the burning will run smoothly. At the time of shaking or tearing, the trees are big enough to be left behind because it is believed that the trees have guards. Cutting of large trees is done by using a machete or sharp ax. Tree felling should not be done by any means, except on Totua Panggare 'decision. This activity is carried out jointly by all KAT residents that are in one group and usually a week after the land plotted. 
Before felling of large trees, rituals were also performed, (Mompakoni puenggayu) where in this occasion the customary leaders had to slough again six chickens then cooked and served together with rice whose produced from customary land. Before the food being consumed together in the area the big trees locate, the customary leader read the mantras in local language which essentially means: "O gods guard...., We came here to find a livelihood. Please do not disturb us. Give us a chance to this place....., since the god has a better place in the big trees outside there..."

The ritual activities were carried out because of the KAT people's belief that there is a subtle creature (forest guard on the mountain) that stay in a large tree. So it needs to be moved with respect. With the move of the spirits then it is believed will not interfere with the KAT residents that will carry out farming activities.

\section{(g) Drying (nabangi).}

After trees were cutting, the bushes of the trees were dried, it usually lasts approximately one month. While waiting for bushes dry they planted bananas and look for any food in the forest for family consumption. However, when they are settled on permanent location, they grow cocoa and other cash crops together with seasonal crops.

\section{(h) Burning (muhube/montilomba).}

Burning bushes or trees that have been cut down has to be done first by the Totua Panggare'. By using moti (a stick that has been recited a mantra) that was placed at any corner of the boundary of bushes to be burned, the Totua Panggare was able to burn the forest without the fire passing the planned boundary of the burning area. Rambo and Sajise (1984) and Iskandar (1992) mentioned that there are at least six advantages of burning in shifting cultivation system: (1) Cleaning unwanted vegetation in fields; (2) change the soil structure so that the plants are not easy to grow; (3) Improving soil fertility with ash inputs from vegetation burning; (4) Reduce soil acidity; (5) Increasing the availability of nutrients; and (6) For sterilization of soil and reducing pest organisms and pest plants.

\section{(i) Planting (mutuda)}

KAT residents must plant local rice on customary land. If not, they will feel very sinful and always haunted will get a disaster. Their belief that rice and fields is manifestations of human beings so that they considered to be part of them. In that connection, they believe in two important things: (1) if they do not plant rice, it's just the same breaking the spiritual relationship between themselves with their ancestors; (2) continuous rice cultivation on the same land by not allowing the land to rest, they consider as a rebellion to their ancestor.

The rice cultivation system practiced by the KAT residents in North Mamuju District has similarity with the rice cultivation system managed in several places in Indonesia, as it was revealed by Triguna (2006) that the ritual process in agriculture and rice cultivation can strengthen at every level of activity, because everything is seen as sacred or purified.

Likewise, with local rice planted by the KAT Residents in North Mamuju, based on its history, the indigenous communities carried out shifting cultivation with a period approximately 10-15 years required before return to the initial one. However, due to the change of socioeconomic and demographic conditions (including settled settlement and the presence of big company) the period becomes short as presented in Table 2. 
Table 2. The fallow period of land before and after settlement

\begin{tabular}{llcc}
\hline \multirow{2}{*}{ No } & \multicolumn{3}{c}{ The fallow period } \\
\cline { 2 - 4 } & Group/ Settelement of KAT & $\begin{array}{c}\text { Before settlement } \\
\text { (year of 1970-an) }\end{array}$ & $\begin{array}{c}\text { After settlement } \\
\text { (in the last 10 years) }\end{array}$ \\
\hline 1 & Bamba Apu & $5-10$ years & $2-3$ years \\
2 & Bamba Mone & $5-10$ years & $0-3$ years \\
3 & Pelontu & $5-10$ years & $2-3$ years \\
4 & Kalibamba & $5-7$ years & $2-3$ years \\
5 & Tosonde & $5-7$ years & 2 years \\
6 & Wulai & $5-7$ years & $0-2$ years \\
\hline
\end{tabular}

Source: FGD result from every settelement group, 2010.

The residents of KAT consider the importance of fallow periods to their field rice production. Whether those who are still practicing shifting cultivation systems, or temporarily not practicing shifting cultivation, all reveal that the fallow period are closely related to the level of paddy field production. The longer the land is rested, the more fertile the forest becomes. If the land is reopened into new cultivation then it is planted with maize and rice, causing high levels of corn and paddy production to be high when compared to short fallow periods.

The planting of rice in shifting cultivation system begins with seed preparation which was prepared early along with the rice harvest. When the KAT residents carry out the rice harvest, at that time they also separated the paddy which is expected to be good seed for the next planting period. The number of seed prepared normally for a 1 ha bonta area is two cans (belle') (1 cans is about 20 liters of paddy). The seeds were planted with spacing of $40 \mathrm{~cm} \times 40 \mathrm{cms}$. The rice grown is local rice cultivar that they call as Salene rice and Manjavanga rice. The first planting was done by the Totua Panggare. Before planting they do a ritual in the form of offerings. Rice plantation is usually done in October (depending on rain) with a period of 5-7 days for each field. This activity is carried out in rotation with mutual help (gotong royong) system. Traditional tools used are hoes or pohaku (tugalan) a tool made of a wooden stick that is about $1 \mathrm{~m}$ long and one end is sharpened.

\section{(j) Crop maintenance}

In general, crop maintenance is very important in order to obtain optimal production. However, in shifting cultivation systems, it does not require much maintenance except weeding. The weeding is usually done twice. The first weeding is done when the rice is about one month old and the second weeding is about two months old after planted. Fertilization is not done on rice farming. While the pest controls strategy at once realized when passing shifting fields. In ancient times (prior to settlement), the newly opened cultivation lies far from the previous cultivation. In addition, to religious reasons, there are other reasons to avoid pests. Animals known as pests include pigs, rats, grasshopper, and caterpillars.

The pest can be controlled by a mosambulu ceremony (ceremony rejecting reinforcements or pests). In this ceremony prepared "ota" and burning "incense " while recited the mantra by the Totua Panggare. The purpose of this activity is to repel pests so as not to disturb the plant. Besides pest control strategies, there is also a special treatment conducted by KAT residents when rice starts flowering to obtain optimal field rice production. The special treatment (tradition) referred to as the conclusion of the following FGD results: 
"When the rice begins to bloom, there is a member of the group that takes the rattan leaf and then puts it by the Totua Panggare on one of the rice groves on a plot (bonta) in a langa. A working group of farmers usually occupies 3-5 langa (according to the number of households managing the cultivation). Thus, the number of rattan leaves that are installed ranges of 3 to 5 units (depending on the number of langa/working groups of farmers under the leadership of a Totua Panggare'). In addition, KAT residents should not be voiced and should not work for seven days and seven nights. Who is in violation, fined with money, ceramic plates or other fines decided by customary figures. The meaning of the two rules is that the flowers of rice in a langa are not empty."

\section{(k) Harvest}

After the rice is about six months old, then the rice is ready to be harvested. Before harvesting, An offer to the bonta performed by using rice and songkolo (sticky rice) or leman (sticky rice cooked in bamboo ) that produced from customary land, six chickens or one pork that cooked by chilly.

Rice harvesting is done individually, means that each family harvested their rice on the bonta that is entitled to it. Period of harvest for each bond may last up to one week . The rice is harvested traditionally by using ani-ani (sickle ). The stalks of harvested paddy were tied up by using bamboo straps. One bunch of stalk rice is called a Basse (wesse). Rice bundles then are collected and stored on bamboo poles. After the harvest, the paddy is threshed traditionally (by trampling/direse'), then dried and placed in a kulili in the barn house (on the mountain).

At harvest time, it is prohibited from others (who are not bonta owners) to cross the cultivator's road to garden house to langa (where the rice will be harvested). If this norm is violated, then it is believed by KAT citizens that the harvest is not maximal or shrinking from the actual amount. Thus, if anyone breaks the rules imposed sanctions. Although in reality very rare violations associated with the rule. In the past, people that violated the rules were sanctioned with a set of plates. If one does not have a plate then the person that broke the rules must guarantee the victim of to one year. But the rule was considered too harsh and was considered and ultimately not treated again. Sanctions given if there is a violation of customary rules, decided by customary leaders. The usual sanctions imposed by customary figures of those who violate the norm and can not afford to pay a fine are detained in the victim's house (the person who crossed/cut his way) until the harvest is complete. Even if in the end of the penalty (penalty) is considered complete, they are usually given grain to go back home to the customary land.

\section{Conclusion}

The practice of indigenous cultivation of indigenous communities To Ri Bunggu is carried out from generation to age by taking into account the ecological balance. They develop local wisdom as a guide to farming led by traditional leaders (the elders). Various rituals are performed in the farming process such as in opening the field for cultivation by asking permission from the viata (ancestral spirits and dead relatives). As a manifestation of the will to harmony with nature. For them, nature must be respected as a mother (indo) whom they understand as giving love and life. 


\section{References}

Ali, M. Saleh S. (2000). Local knowledge and sustainable agricultural development: perspective of the marginalized. Speech of Inauguration Professor, Faculty of Agriculture and Forestry, Universitas Hasanuddin, Makassar, South Sulawesi, Indonesia.

Dharmakusuma, S. (2008). Dampak Pembangunan Terhadap Masyarakat Terasing (Impact of Development to Remote Community) http://id-jurnal.blogspot.com/2008/04/

Husnah, N., Ali, M. S. S, Salman, D., Hijjang, P., (2014). “Merging Indigenous and Modern Knowledge in Agricultural Development." International Journal of Agriculture System. Volume 2 (2): 141-151.

Iskandar, J. (1992). Ekologi Perladangan di Indonesia (Ecology of Shifting Cultivation in Indonesia). Djambatan. Jakarta.

Kamaluddin, A., Husnah, N., Busthanul, N., Ali, M.S.S., (2016). "Pananrang": A Guidance of Buginese Farmers in Farming. International Journal of Agriculture System. Volume 4 (2): 168-177

Kantor Dinas Sosial Kabupaten Mamuju Utara, (2010). Laporan: Jumlah Penduduk KAT di Kabupaten Mamuju Utara (Report: Total Population KAT in North Mamuju District).

Mulyoutami, E., van Noordwijk, M., Sakuntaladewi, N. and Agus, F. (2010). Perubahan Pola Perladangan: Pergeseran persepsi mengenai para peladang di Indonesia (Changes of Shifting Cultivation Pattern: Shifting perceptions of the Swidden cultivators in Indonesia. Bogor, Indonesia. World Agroforestry Centre - ICRAF, SEA Regional Office. 101p.

Michael R. Dove, M. R., (1985). Swidden Agriculture in Indonesia: The Subsistence Strategies of the Kalimantan Kantu'. New York: Mouton.

Purwana, B.S and Sukasmanto. (2007). Analisis: Eksploitasi Lingkungan dan Perlawanan Masyarakat Adat di Kalimantan Barat (Analysis: The Exploitation of the Environment and the Resistance of Indigenous Peoples in West Kalimantan).

Rahmadanih, (2010). Sosio-Budaya Pangan Pada Komunitas adat Terpencil di Kabupaten Mamuju Utara, Sulawesi Barat (Socio-Cultural Food on Remote Indigenous Communities in North Mamuju Regency, West Sulawesi). Dissertation, Graduate School, Hasanuddin University.

Rambo, A.T., Sajise, P. E., (1984). An Introduction to Human Ecology Research on Agricultural Systems in Southeast Asia. University of the Phillippines at Los Baños.

Salam, M. (2005). Modul Metodologi Penelitian Kualitatif (Module of Qualitative Research Methodology).

Soemarwoto, O. (2001). Ekologi Lingkungan Hidup dan Pembangunan (Environmental Ecology and Development). Djambatan. Jakarta.

Triguna, IBG.Y. (2006). Prospek Kebudayaan Pertanian dalam Kehidupan Kesejagatan dalam Revitalisasi Pertanian dan Dialog Peradaban (The Prospect of Agricultural Culture in World Life in Revitalization of Agriculture and Dialogue of Civilization. Buku Kompas. Jakarta. 